Elena Lisanyuk ${ }^{1}$

\title{
HINGES, DEEP DISAGREEMENT AND FIXED POINTS IN THE ARGUMENTATION LOGIC2
}

Abstract. In his treatise 'On Certainty' (1969) L. Wittgenstein compared the propositions expressing basic principles to the hinges enabling both doubting and justifying knowledge. In 1985 Robert Fogelin proposed the conception of deep disagreement in argumentation analysis and in his description of it he referred to the hinges. We continue Wittgenstein's hinges metaphor and compare pulling and pushing the door of knowledge to adopting contrary standings about principal issues, which can result in the deep disagreements. We suggest looking at the hinges enabling those door moves as at the fixed points in the extension semantic of the argumentation logic. Interpreting the hinges as the fixed points allows viewing rejected arguments as isolated deadlocks of the deep disagreements, or anti-extensions, and opens a possibility for a compromise on the basis of certain extensions.

Keywords: argument, abstract argumentation framework, extension semantic, Ludwig Wittgenstein, Robert Fogelin.

Аннотащия. В трактате «О достоверности» (1969) Л. Витгенштейн сравнил предложения, выражающие ключевые принципы знаний людей, с дверными петлями, без которых невозможно ни обосновывать знание, ни сомневаться в нём. В 1985 году Роберт Фогелин предложил понятие глубокого несогласия для анализа аргументации и, описывая его свойства, сослался на дверные петли Витгенштейна. Если продолжить метафору дверных петель Витгенштейна, то, если дверь познания толкают или тянут, это ведет к глубоким разногласиям по принципиальным вопросам. В русле этого мы предлагаем посмотреть на дверные петли как на неподвижные точки в семантике расширения логики аргументации. Это позволяет рассматривать отклоненные аргументы как изолированные тупики глубоких разногласий и открывает возможность для компромисса на основе определённых расширений.

Ключевые слова: аргумент, абстрактные структуры аргументации, семантика расширений, Людвиг Витгенштейн, Роберт Фогелин.

Для цитирования: Lisanyuk E. Hinges, Deep Disagreement and Fixed Points in the Argumentation Logic // Логико-философские штудии. 2021. T. 19, № 1. С. 112 116. DOI: 10.52119/LPHS. 2021.92.34. 008 .

The conception of deep disagreements which 'cannot be resolved through the use of argument, for they undercut the conditions essential to arguing' (Fogelin 2005: 7-8)

\footnotetext{
${ }^{1}$ Elena Lisanyuk, St. Petersburg State University and National Research University Higher School of Economics.

e.lisanuk@spbu.ru

${ }^{2}$ Support from the Russian Science Foundation, project no. 20-18-00158 'Formal Philosophy of Argumentation and comprehensive methodology of search and choice of dispute resolutions' is kindly recognized.
} 
was proposed by Robert Fogelin in 1985 as a development of Ludwig Wittgenstein's idea that 'the questions that we raise and our doubts depend on the fact that some propositions are exempt from doubt, are as it were like hinges on which those turn' (Wittgenstein 1969: 341). Among the sources of deep disagreements are moral and political views, routine rules of social life and reasoning and lack of knowledge when the science is silent or gives ambivalent answers to our questions.

Fogelin illustrates the deep disagreements with two examples. The first is the abortion dispute which refers to the issue of when exactly the human soul is born, prior to baby's birth, or shortly after that. The pro-lifers justify their anti-abortion claim by referring to the former which confronts the latter held by the pro-choicers. Another Fogelin's example is a political stand-off about positive discrimination. Opposing parties agree that it is good practice, but disagree on its procedure. Should it be endorsed as a mechanism for making the chances for better life equal for people raising from unequal households, which risks privileging less competent, or as a mechanism for protecting the members of a certain group, from which may benefit those who were never really discriminated? The first example is about an epistemic deep disagreement rooted in our ignorance, although it is often presented as a moral stand-off. The other one appears a cognitive disagreement about why we may need the positive discrimination, but in fact it is a disagreement the routine of social practice. Because of the parties' disagreement about what that practice should amount to they are likely to bury such a bill, if it were put on vote. This shows that although the deep disagreement has a local character it still endangers a consensus about an issue.

Wittgenstein described the hinges as the propositions expressing key principles preferred by rational agents, which have the following two properties:

(i) they are non-factual propositions expressing agents' preferences, and not their beliefs about situations, which makes the preferences as shaky as the reasons proposed in support of them,

(ii) at least one dispute party refers to her preference as commonly shared and 'declares the other a fool and heretic' (Wittgenstein 1969: 611) for disbelieving it.

Property (ii) often show up in the ad hominem and common-sense arguments used by one party for refuting not only the contrary claim but the person of the other party as well. The ad hominem and common-sense arguments belong to the plausible, or presumptive, arguments which are non-demonstrative. They can be sound or not depending on the course of dispute where they are used (Walton 1996). While in one dialogue the plausible arguments can provide a support for its conclusion yet in another dialogue they can be fallacious. The personal attack conveyed by (ii) marks out the deep disagreement in either way.

Property (i) gave rise to the so-called hinges epistemology (Ranalli 2020) with its key issue of whether the hinges are propositions held either true or false by the confronting parties (Kusch 2016; Coliva 2015), they are rules for proofs and discussions (McGinn 
1989; Moyal-Sharrock 2005) or they are neither of them (Wright 2014; Pritchard 2016). The propositional view treats the hinges as conceptual disagreements in the epistemic sense, similar to that in the abortion example, whereas the rules-related view turns the disagreements into the cognitive diversity which can be viewed as the logical diversity, too (Лисанюк, Павлова 2016). The propositional and rule-related view of the hinges relate them to the widely held conception of knowledge as justified true belief with the verification as its key tool for distinguishing propositions expressing true knowledge from those which are not so.

The third position generated a variety of the hinges interpretations to which belongs Fogelin's idea that that they express 'moral standing'. He proposed another pair of properties of the deep disagreement (Fogelin 2005: 10-11):

(iii) the parties 'can agree on all historical and statistical issues, but still disagree',

(iv) the deep disagreement cannot be resolved by conviction but can be- by persuasion.

Proposed in (iv) persuasive ways of dispute disagreement allow employing the nondemonstrative reasoning, if the demonstrative one fails. Non-demonstrative reasoning imply the idea of knowledge as defeasible and falsifiable, according to which a true proposition once justified and regarded knowledge can be disregarded later. Consequently, a rational agent believes in propositions she can justify rather by defending them with arguments against the counterarguments in favor of the contrary proposition than by verifying them by means of inferring them out of some other propositions (Pollock 2010).

(i) and (ii) suggest that whatever is the issue of the disagreement it leads into a deadlock the parties engaged in it, since the shared reliance for its resolution is empty. (iii) points to a way for the parties' compromise by isolating the dispute deadlocks labelled by the rejected arguments and focusing on the subsets of arguments proved acceptable.

The concept of (defeasibly) acceptable argument is central in the argumentation logic, a new branch of logic for studying argumentation, which emerged at the crossroad of AI, argumentation and logic in the 90s. The argumentation logic employs the procedural semantic which allows determining of the solutions of the argumentative disputes by identifying them with the definite extensions of the subsets of the acceptable arguments on the argumentation framework. The argumentation framework $F$ symbolizes a dispute $F=\langle A r g$,attack $\rangle$ in which $A r g$ is a set of arguments $\operatorname{Arg}=\left\{A, B, \ldots, X_{n-1}, X, \ldots\right\}$ and attack is a binary abstract relation modelling objection against a disputed conclusion: if $A$ objects $B$, attack $[A, B]$, then $B$ is rejected, unless there is another argument $X$ such as attack $[X, A]$ and $\operatorname{attack}[X, B]=\emptyset$, which reinstates $B$ (Dung 1995). An acceptable argument supports a conclusion for which there is no acceptable argument supporting the contrary conclusion, such as $X$, or which refutes the argument supporting the contrary conclusion, such as $B$. 
The credulous and skeptical algorithms of the procedural semantic propose two ways of computing the subsets of the acceptable arguments (Лисанюк 2015). According to the skeptical algorithm, the dispute consisting of $\operatorname{attack}[A, B]$ and $\operatorname{attack}[B, A]$, as in Nixon diamond, the well-known example for illustrating default reasoning, results in an empty extension, and in two stable extensions, $A$ and $B$, according to the credulous algorithm. Informally, a skeptical reasoner gets convinced by a conclusion only if it is supported by the arguments refuting the arguments in favor of the contrary conclusion. For a credulous reasoner, any argument in favor of a conclusion is convictive, unless it is refuted.

The extension semantic employs the concept of fixed point introduced by (Kripke 1975: 702), which in terms of the argumentation frameworks amounts to a pair of arguments $\phi, \psi \in F$, attack $[\phi, \psi]$ in relation to which any other argument $\gamma_{1}, \ldots, \gamma_{n} \in$ $F$ is either acceptable or rejected, despite of the fact whether some of $\gamma_{1}, \ldots, \gamma_{n}$ are attacked or not. The extension semantic of the argumentation logic allows viewing the deep disagreements as the fixed points of a dispute, which divide its set of arguments into the extension and anti-extension. Thus, after a skeptical reasoner adopts $\psi$, the fixed point, she may claim ' $\gamma_{i}$, since $\phi$ ', but she cannot claim ' $\gamma_{i}$, since $\psi$ ', for $\psi$ is rejected by the attack. Suppose that attack $[\psi, \phi]$, which turns $\psi$ and $\phi$ into the extension and anti-extension. Now, adopting $\psi$ or $\phi$, but not both is available for a credulous reasoner only, who is also free to adopt any of $\gamma_{1}, \ldots, \gamma_{n}$ and pick out referring to $\psi$ or $\phi$ to justify that. Looking at the hinges as at the fixed points in the extension semantic elaborates property (iii) of the deep disagreement and abstracts from its properties (i), (ii) and (iv).

Let us sketch the advantages of viewing the deep disagreements as the fixed points, or the hinges of the disputes. It preserves the local character of the disagreement, as the computing the dispute resolutions by means of the extensions on the argumentation framework is dialog related. It allows employing the non-demonstrative persuasion along with the demonstrative conviction, for on the argumentation frameworks arguments are evaluated as acceptable or not irrelevantly of their logical structure. Since the abstract argumentation approach treats arguments as unanalyzed elements of the argumentation framework $\mathrm{F}$, and to be the arguments it suffices that they are put forward as objections or supports for some conclusions, their eligibility to function as arguments is independent of them being atomic propositions or molecular arguments. Although the conclusions defended in this way in the credulous or skeptical algorithm can be called true in a wide sense, nevertheless the procedural truthfulness of them differs from what logicians call true propositions in the denominative sense. It is one of the reasons of why some analysts doubt that the abstract argumentation approach belongs to the domain of logic (Prakken, Vreeswijk 2002); yet others suggest treating that approach as a general view of defeasible inference and defining the deductive inference as an indefeasible species of it (Kakas et al. 2018). Thus, looking at the hinges as at the fixed points allowing pushing and pulling the knowledge door will turn the 
Elena Lisanyuk. Hinges, Deep Disagreement and Fixed Points in the Argumentation Logic

deep disagreements into results of those moves. Interpreting the hinges as the fixed points in the abstract argumentation semantic algorithms corresponds to the third way of understanding of what the hinges are, it generalizes treating them as propositions or rules.

\section{References}

Coliva 2015 - Coliva A. Extended rationality: A hinge epistemology. London: Palgrave Macmillan, 2015.

Dung 1995 - Dung P. M. On the acceptability of arguments and its fundamental role in nonmonotonic reasoning, logic programming, and $n$-person games // Artificial Intelligence. 1995. Vol. 77. P. 321-357.

Fogelin 2005 - Fogelin R. J. The Logic of deep disagreement // Informal Logic. 2005 [1985]. Vol. 25, no. 1. P. 3-11.

Kakas et al. 2018 - Kakas A., Mancarella P., Toni F. On Argumentation Logic and Propositional Logic // Studia Logica. 2018. Vol. 106. P. 237-279.

Kripke 1975 - Kripke S. Outline of a Theory of Truth // Journal of Philosophy. 1975. Vol. 72, no. 19. P. 690-716.

McGinn 1989 - McGinn M. Sense and Certainty: A Dissolution of Scepticism. Oxford: Blackwell, 1989.

Moyal-Sharrock 2005 - Moyal-Sharrock D. Understanding Wittgenstein's On Certainty. London: Palgrave Macmillan, 2005.

Pollock 2010 - Pollock J. L. Defeasible Reasoning and Degrees of Justification // Argument and Computation. 2010. Vol. 1, no. 1. P. 7-22.

Prakken, Vreeswijk 2002 - Prakken H., Vreeswijk G. Logic for Defeasible Argumentation // Handbook of Philosophical Logic / ed. by D. M. Gabbay and F. Guenthner. Vol. 4. Kluwer: Dordrecht, 2002. P. 218-319.

Pritchard 2016 - Pritchard D. Epistemic Angst. Radical Skepticism and the Groundlessness of Our Believing. Princeton University Press, 2016.

Ranalli 2020 - Ranalli C. Deep disagreement and hinge epistemology // Synthese. 2020. Vol. 197. P. 4975-5007.

Walton 1996 - Walton D. Argumentation Schemes for Presumptive Reasoning. NY: Lawrence Erlbaum Associates, 1996 (2001).

Wittgenstein 1969 - Wittgenstein L. On Certainty / ed. by G. E. M. Anscombe, G. H. von Wright. New York and Evanston: J\&J Harper, 1969.

Wright 2014 - Wright C. On epistemic entitlement (II). Welfare state epistemology // Scepticism and Perceptual Justification / ed. by D. Dodd, E. Zardini. OUP, 2014. P. 213-247.

Лисанюк 2015 - Лисанюк E. Н. Аргументация и убеждение. СПб: Наука, 2015.

Лисанюк, Павлова 2016 - Лисанюк E. H., Павлова A. M. Логические аспекты многообразия агентов // Известия Уральского федерального университета. Сер. 3. Общественные науки. 2016. Т. 11, № 4. С. 45-60. 